\title{
STUDY OF THE ALLELE POOL AND THE DEGREE OF GENETIC INTROGRESSION OF SEMI-DOMESTICATED AND WILD POPULATIONS OF REINDEER (Rangifer tarandus L., 1758) USING MICROSATELLITES
}

\author{
V.R. KHARZINOVA ${ }^{1}$, A.V. DOTSEV 1 , A.S. KRAMARENKO ${ }^{2}$, K.A. LAYSHEV ${ }^{3}$, \\ T.M. ROMANENKO ${ }^{4}$, A.D. SOLOV'EVA ${ }^{1}$, T.E. DENISKOVA ${ }^{1}$, O.V. KOSTYUNINA ${ }^{1}$, \\ G. BREM1, 5 , N.A. ZINOVIEVA ${ }^{1}$
}

${ }^{1}$ L.K. Ernst All-Russian Research Institute of Animal Husbandry, Federal Agency of Scientific Organizations, 60, pos. Dubrovitsy, Podolsk District, Moscow Province, 142132 Russia, e-mail veronika0784@mail.ru, asnd@mail.ru, anastastasiya93@mail.ru, horarka@yandex.ru, kostolan@mail.ru, n_zinovieva@mail.ru;

${ }_{2}^{2}$ Mykolayiv National Agrarian University, 9, vul. Georgiya Gongadze, Mykolayiv, 54020 Ukraine, e-mail kssnail@mail.ru;

${ }^{3}$ North-West Center of Interdisciplinary Food Research, 7, sh. Podbelskogo, St. Petersburg-Pushkin, 196608 Russia, e-mail layshev@mail.ru;

${ }^{4}$ Naryan-Mar Agricultural Experimental Station, Federal Agency of Scientific Organizations, 1a, ul. Rybnikova, Naryan-Mar, Nenets Autonomous District, 166004 Russia, e-mail nmshos@atnet.ru;

5 Institut für Tierzucht und Genetik, University of Veterinary Medicine (VMU), Veterinärplatz, A-1210, Vienna, Austria, e-mail gottfried.brem@agrobiogen.de

Acknowledgements:

Supported by Russian Science Foundation (project № 16-16-10068)

Received September 5, 2016

\section{Abstract}

The coexistance of domestic and wild reindeer populations (Rangifer tarandus L., 1758) is an important feature of this species. Both forms inhabit in conditions, which remain substantially unchanged for a long time. Due to gene flow between domestic and wild populations we observe a relatively high amount of admixture in the gene pool. Biodiversity characteristics of two most numerous reindeer populations (semi-domesticated Nenets breed and wild population of reindeer inhabiting territories of Nenets Autonomous Okrug (NAO) and Taimyr Autonomous Okrug (TAO) based on the analysis of microsatellites are given and the degree of introgression in these populations is determined. Samples of Nenets breed of domestic rein deer were collected in several farms in NAO and TAO ( $n=115$, four subpopulations). Samples of wild Taimyr population were collected in the course of field research in different geographic regions of TAO ( $n=63$, five subpopulations). Genomic DNA was isolated using Nexttec columns («Nexttec Biotechnologie GmbH», Germany). Polymorphism of 9 STR-loci (NVHRT21, NVHRT24, NVHRT76, RT1, RT6, RT7, RT9, RT27, RT30) was determined according to the previously developed technique for DNA analyzer ABI3130xl («Applied Biosystems», US). To estimate the allele pool of each population average number of alleles $(\mathrm{Na})$, the effective number of alleles $(\mathrm{Ne})$ based on the locus, rarified allelic richness $\left(\right.$ Ar), private allelic richness $(\mathrm{PrAr})$, observed $\left(\mathrm{H}_{\mathrm{o}}\right)$ and expected $\left(\mathrm{H}_{\mathrm{e}}\right)$ heterozygosity and inbreeding coefficient $\left(\mathrm{F}_{\mathrm{IS}}\right)$ were calculated. The degree of genetic differentiation of populations was assessed

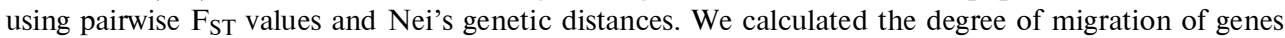
between populations based on microsatellite allele frequencies. Distribution of genetic variation between and within populations was studied by analysis of molecular variance (AMOVA). It was found that the wild population of reindeer is characterized by a higher level of genetic diversity: the average number of alleles per locus was $10.00 \pm 0.78$ vs. $8.44 \pm 0.80$, the observed heterozygosity $0.633 \pm 0.060$ vs. $0.589 \pm 0.049$. STRUCTURE analysis revealed the formation of two independent clusters corresponding to the wild and domestic populations with high values of the membership coefficient in own clusters: $\mathrm{Q}_{\mathrm{WLD}}=0.940 \pm 0.013$ and $\mathrm{Q}_{\mathrm{DOM}}=0.938 \pm 0.010$. However, a few individuals (4.4-4.8\%) carrying a mixed genetic origin were found. The degree of introgression between the populations was around $6 \%$. Cluster analysis of genetic structure performed separately for wild and domestic populations at the level of subpopulations for the number of cluster $\mathrm{k}$ ranged from 2 to 5 did not reveal a clear clustering between subpopulation. It's confirmed the homogeneity of genetic structure within populations. Examination of overall genetic diversity with AMOVA procedure indicated that most of the variation was observed within populations (95.4\%, p $<0.001)$. Principal component analysis (PCA) revealed clear differentiation of the studied domestic and wild popula- 
tions along the axis 1 with their slight overlapping; herewith the principal component 1 was responsible for $5.15 \%$ of variability. Evaluation of differentiation degree between subpopulations of rein deer, performed by calculation of the pairwise values of $\mathrm{F}_{\mathrm{ST}}$ and Nei's genetic distances (DN) showed relatively higher degree of genetic differentiation between subpopulations within wild population comparing to domestic population (maximal $\mathrm{F}_{\mathrm{ST}}$ and $\mathrm{DN}$ values were 0.046 vs 0.023 and 0.353 vs 0.151 , respectively). The obtained results of genetic diversity and population structure of reindeer will be used to develop the breeding program with Nenets breed of domestic rein deer and to organize the measures for protection and sustainable use of wild reindeer bioresources.

Keywords: allele pool, introgression, populations, reindeer, microsatellites

Reindeer breeding is one of the oldest animal industries that takes the leading place in agriculture and commercial industry of the Far North. This is the only agricultural industry in which 18 indigenous minorities numbering over 130,000 people, mostly rural dwellers, are directly or indirectly involved [1]. Due to reindeer in the tundra and forest tundra zones, millions of hectares of pastures unavailable to other animals are effectively used [2]. According to the Arctic Council's project "Sustainable Reindeer Breeding" [3)], Russia has about $2 / 3$ of the world's domestic reindeer stock browsing in tundra, forest tundra, boreal forest, and mountain regions throughout the territory of over $3 \mathrm{mln} \mathrm{km}^{2}$.

Reindeer (Rangifer tarandus L., 1758) is the only representative of Rangifer C. H. Smith, 1827. For a historically long period, a large group of domestic reindeer was bred with clearly expressed morpho-biological and useful sustainably inherited traits. In 1985, four reindeer breeds were approved and entered into the State Register: Nenets, Chukotka, Evenk, and Even. For the last decade, the number of domestic reindeer in Russia reduced 2-fold and as of 1 January 2012 was assessed at 1,583,000 livestock units, which amounted only to $70.0 \%$ as compared to 1990 [4].

The Nenets indigenious reindeer breed is the largest in Russia by the number (950,000 livestock units) and pasture territory (110 million ha) [5]. The reindeer of this breed are of an average size with rather well-defined working characgeristics [6]. They are perfectly adapted to the local climate conditions [7]. The Nenets reindeer are widely spread in the Nenets, Yamalo-Nenets, Khanty-Mansi, and Tamyr Autonomous Okrugs, Murmansk and Arkhangelsk regions, and the Republic of Komi. According to the breeding records as of 1 January 2015, there are about 170,000 reindeer bred by 23 farms in the Nenets Autonomous Okrug (NAO) [8]. Despite the existence of several ecological geographic types, the Nenets indigenous reindeer are the most homotypic and consolidated. Larger species can be found only on the arctic islands (Kolguev, Vaigach, etc.), which is explained by favorable feeding conditions, rather than genetic peculiarities [9].

The number of wild reindeer has also reduced for the said period [1012]. Currently, their number is 1.4 million livestock units, with over $70 \%$ concentrated in the north of Middle Siberia. The largest population is the Taymyr population which is of exclusive value as a key component of Taymyr biodiversity. Wild reindeer largely determine the conditions for vegetation recovery, and are the species that affect the habitat of mammals and birds in the region $[13,14]$. The Taymyr reindeer population is a geographic and ecological phenomenon having no analogs by the number, the distance of migrations (up to $1,500 \mathrm{~km}$ ), and the coverage of zonal types (from the northern tundra to polar deserts) [15].

The co-existence of domestic and wild forms is an important peculiarity of the species. Domestic reindeer does not differ substantially from its wild ancestor. Both forms dwell in almost similar conditions that remain practically unchanged for a long time. In reindeer breeding, no artificial forage is used and there are no 
zootechnical methods of feeding or artificial management. Domestic reindeer are range-fed and feed on the same forage as their wild congeners, but consume forage resources more fully as they do not migrate for long distance [3]. Discussing the intraspecific status of the domestic reindeer, some authors believe that in the same geographical areas it forms a common genetic pool with the wild species [16].

For the reindeer breeding industry, the existence of domestic and wild reindeer forms poses a serious problem [11], which, among others, may be caused by the withdrawal of domestic reindeer by wild ones, grazing of pastures and mutual pasture competition, remaining centers of infections, and transfer of diseases. The most serious are the first two reasons resulting in a complete loss of domestic reindeer breeding in the central part of Taymyr Peninsula, and a substantial reduction of domestic reindeer livestock in Eastern Taymyr and some other regions [17]. In this respect, E.E. Syroechkovskii [18] and L.M. Baskin [19] think that a decrease in the wild reindeer population is caused by intensive development of domestic reindeer breeding that extensively ousts the wild population.

It is ascertained that domestic and wild populations exchange genes which mixes their gene pool. Along with evolution factors (gene drift, mutations, natural selection), the population gene pool also changes under the influence of the migration process. The divergence between the populations may be caused by the genetic drift because of full or partial isolation and heterogenetic selection among sub-populations. The animal migrations, no matter how insignificant they are, prevent divergence and reduce the genetic diversity among populations, but at the same time increase this parameter within sub-populations [20].

The key live-stock animals (cattle, sheep, swine, goats, horses, hens, dogs) were domesticated several thousand years ago [21, 22], their genetic variability preserves inside and between the species, and they substantially differ from their wild predecessors [23, 24]. Although reindeer were domesticated 5-10 thousand years ago $[25,26]$, the wild and domestic populations demonstrate gene exchange [27].

The assessment of genetic divergence and the monitoring of evolution processes may be adequately performed using molecular-genetic methods that provide objective understanding the genetic structure of populations and make it possible to determine the degree of introgression between them [28]. One of the methods widely used to assess the genetic structure of reindeer populations of various subspecies is the analysis of microsatellites (STR, short tandem repeats) [29-33]. Most often, microsatellites are used in population and ecological research to study gene transfer, the effective size of populations, migration, an intraspecific genetic variability and differentiation of populations [34-37].

In this research for the first time ever, the possibility of identifying reindeer species of wild, domestic or mixed forms using highly polymorphic DNA markers has been shown by the example of populations dwelling in the north of Nenets Okrug and Taymyr Autonomous Okrug.

The purpose of this work was to study the allele pool of domestic and wild reindeer populations dwelling in the north of Nenets Okrug and Taymyr Autonomous Okrug and to assess the genetic introgression between them using microsatellites.

Technique. The tissue samples were collected from 178 reindeers (Rangifer tarandus L., 1758), including domestic Nenets reindeer (DOM, $n=115)$ and wild Taymyr reindeer (WLD, $n=63$ ). The animals of the Nenets breed were from two farms in Nenets Autonomous Okrug (NAO), the SRO Ilebts (ILB, $n=17$ ) and SPK Indiga (IND, $n=64$ ), and also from two reindeer breeding 
brigades in Taymyr Autonomous Okrug (TAO), the № 4 in the Dudinka river region (DUD, $n=26$ ) and № 11 in the Pelyatka river region (PEL, $n=9$ ). The samples of wild species were collected during the field research in various geographic regions of TAO: Portnyagino (POR, $n=7 ; 4^{\circ} 8^{\prime} 48.12^{\prime \prime} \mathrm{N}, 107^{\circ} 9^{\prime} 54^{\prime \prime} \mathrm{E}$ ),

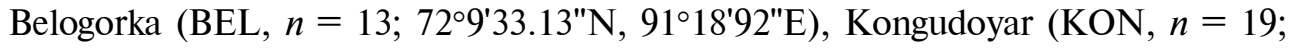
72॰7'62.05"N, 91 36'09"E), Ust-Avam (UAV, $\left.n=20 ; 71^{\circ} 11^{\prime} 40.71^{\prime \prime} \mathrm{N}, 92^{\circ} 82^{\prime} 07^{\prime \prime} \mathrm{E}\right)$ and Volchanka (VOL, $\left.n=4 ; 70^{\circ} 97^{\prime} 60.83^{\prime \prime} \mathrm{N}, 94^{\circ} 54^{\prime} 13^{\prime \prime} \mathrm{E}\right)$. The biomaterial was collected throughout 2016. The sample collection map was built in R-ggmap [38] with visualization in ggplot2 [39].

The genome DNA was isolated using Nexttec columns (Nexttec Biotechnologie $\mathrm{GmbH}$, Germany) in accordance with the manufacturer's recommendations. Polymorphism of 9 STR loci (NVHRT21, NVHRT24, NVHRT76, RT1, RT6, RT7, RT9, RT27, RT30) was determined by the developed methods [33] using a DNA-analyzer ABI3130xl (Applied Biosystems, USA). The allele sizes determined in GeneMapper 4.0 (Applied Biosystems, USA) were converted into numerical expressions used as a basis for the genotype matrix in the MS Excel format.

The allele pool of each population was assessed by determining the average number of alleles $(\mathrm{Na})$ and the effective number of alleles $(\mathrm{Ne})$ per locus [40], the allele diversity estimated by a rarification procedure (Ar), the number of private alleles per locus (PrAr) [41], the observed $\left(\mathrm{H}_{\mathrm{o}}\right)$ and expected $\left(\mathrm{H}_{\mathrm{e}}\right)$ heterozygosity, and the inbreeding coefficient $\left(F_{I S}\right)$ [42]. Genetic differentiation of the populations was assessed based on paired $\mathrm{F}_{\mathrm{ST}}$ values [43] and the genetic distances according to M. Nei [44]. GenAIEx 6.5.1 [45], HP-Rare 1.1 [46] and Genetix 4.05 [47] software was used for calculations.

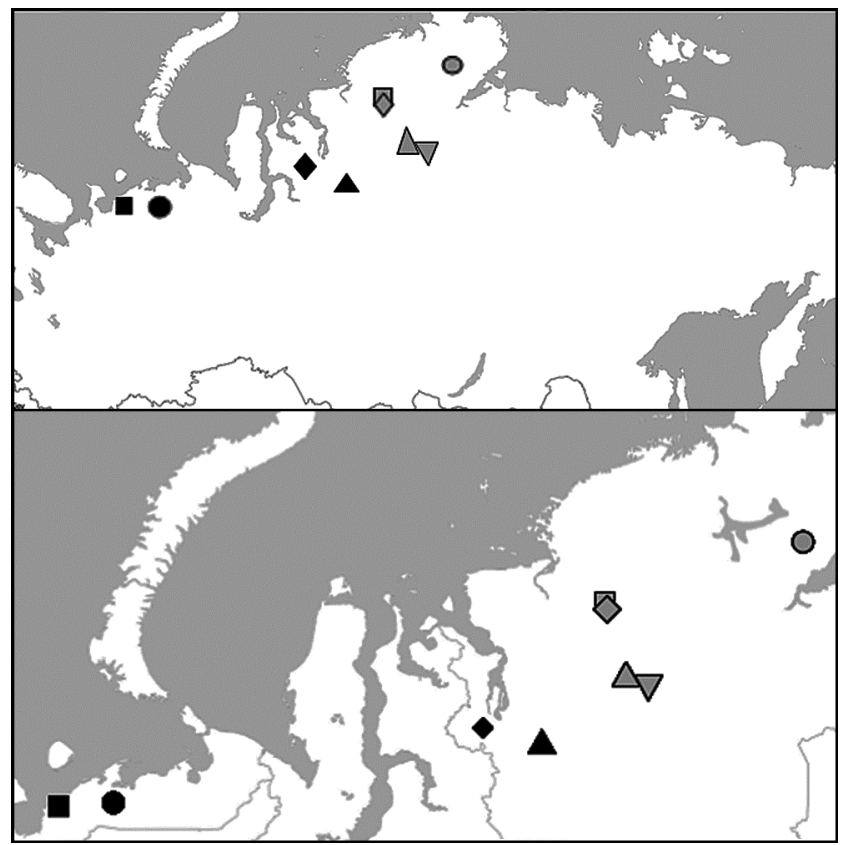

Fig. 1. The points of sampling biomaterial in wild and domestic reindeer (Rangifer tarandus L., 1758) populations: - - ILB, IND, - PEL, $\boldsymbol{\Delta}$ - DUD, - POR, - BEL, KON, $\triangle-$ UAV, $\nabla-$ VOL. For the abbreviation, see the Technique section for description of the sub-populations.
Gene migration between the populations was calculated by the frequency of alleles using the divMigrate graphic network model [48] in $\mathrm{R}$ diveRsity [49]. This model makes it possible to compare the populations based on various assessments of genetic differentiation, such as paired $\mathrm{F}_{\mathrm{ST}}$ values [45], $\mathrm{G}_{\mathrm{ST}}$ [50], $\mathrm{D}_{\mathrm{N}}$ [46], and $\mathrm{D}_{\text {Jost }}$ [51]. Principal Component Analysis (PCA) was performed in $\mathrm{R}$ adegenet [52] with visualization in R gglot2 [39].

Distribution of general genetic variability between and within the populations was studied by AMOVA in Arlequin suite 3.5.2.2 [53]. The genetic structure of the populations was assessed through clus-
odel, with $\mathrm{C}$ from 1 to 6 for tering in STRUCTURE 2.3.4 [54] using a mixed model, with C from 1 to 6 for
the number of expected clusters; 100,000 for the burn-in period, and 100,000 for the Markov chain Monte Carlo model. For each $\mathrm{C}$ value, 10 iterations were per814 
formed. STRUCTURE HARVESTER [55] was used to determine the optimum number of clusters $(\Delta \mathrm{C})$ for the sample assessed by the method of $\mathrm{G}$. Evanno et al. [56]. For each of the samples, an average value of the Q membership coefficient in the i-th cluster was determined for the overall number of clusters (C).

Results. The points of the sample collecting are shown in Figure 1.

The analysis on $\mathrm{Na}, \mathrm{Ne}, \mathrm{Ar}, \mathrm{PrAr}, \mathrm{H}_{\mathrm{o}}$ and $\mathrm{H}_{\mathrm{e}}$ parameters revealed the tendency to higher genetic diversity in the wild population as compared to the domestic one. Both populations demonstrated a deficiency of heterozygotes (Table 1), however, the VOL sub-population had a slight excess of them. A similar pattern is described by K.H. Mager [57] when studying the genetic structure of the wild caribou population in Alaska and the domestic reindeer population in the Seward Peninsula (western Alaska), i.e. Ar from 12.28 to 13.15 and $\mathrm{H}_{\mathrm{e}}=0.86$ for the wild population, $\mathrm{Ar}=10.06$ and $\mathrm{H}_{\mathrm{e}}=0.75$ for the domestic population.

1. Genetic diversity of the wild (WLD) and domestic (DOM) reindeer (Rangifer tarandus L., 1758) populations by microsatellite loci

\begin{tabular}{lr|c|c|c|c|c|c|c}
\hline $\begin{array}{l}\text { Population, sub- } \\
\text { population }\end{array}$ & $n$ & $\mathrm{Na}$ & $\mathrm{Ne}$ & $\mathrm{Ar}$ & $\mathrm{PrAr}$ & $\mathrm{H}_{\mathrm{o}}$ & $\mathrm{H}_{\mathrm{e}}$ & $\mathrm{F}_{\mathrm{IS}}$ \\
\hline POR & 7 & $6.00 \pm 0.62$ & $4.47 \pm 0.61$ & $4.59 \pm 0.39$ & $0.32 \pm 0.14$ & $0.730 \pm 0.065$ & $0.738 \pm 0.036$ & 0.011 \\
BEL & 13 & $7.44 \pm 0.56$ & $5.29 \pm 0.52$ & $4.76 \pm 0.24$ & $0.36 \pm 0.11$ & $0.633 \pm 0.072$ & $0.790 \pm 0.029$ & 0.199 \\
KON & 19 & $8.00 \pm 0.60$ & $5.17 \pm 0.46$ & $4.66 \pm 0.23$ & $0.23 \pm 0.08$ & $0.620 \pm 0.068$ & $0.787 \pm 0.029$ & 0.213 \\
UAV & 20 & $7.89 \pm 0.72$ & $4.74 \pm 0.69$ & $4.42 \pm 0.31$ & $0.29 \pm 0.10$ & $0.617 \pm 0.080$ & $0.741 \pm 0.044$ & 0.167 \\
VOL & 4 & $3.67 \pm 0.50$ & $2.80 \pm 0.45$ & $3.67 \pm 0.50$ & $0.20 \pm 0.10$ & $0.611 \pm 0.074$ & $0.576 \pm 0.056$ & -0.060 \\
WLD & 63 & $10.00 \pm 0.78$ & $5.44 \pm 0.63$ & $4.60 \pm 0.26$ & $2.29 \pm 0.29$ & $0.633 \pm 0.060$ & $0.786 \pm 0.035$ & 0.195 \\
ILB & 16 & $5.56 \pm 0.65$ & $3.39 \pm 0.50$ & $3.60 \pm 0.35$ & $0.10 \pm 0.03$ & $0.563 \pm 0.052$ & $0.643 \pm 0.056$ & 0.125 \\
IND & 64 & $7.22 \pm 0.66$ & $3.97 \pm 0.43$ & $3.88 \pm 0.21$ & $0.11 \pm 0.05$ & $0.603 \pm 0.045$ & $0.723 \pm 0.030$ & 0.167 \\
DUD & 26 & $6.44 \pm 0.56$ & $3.67 \pm 0.53$ & $3.74 \pm 0.27$ & $0.15 \pm 0.04$ & $0.556 \pm 0.067$ & $0.684 \pm 0.042$ & 0.188 \\
PEL & 9 & $5.89 \pm 0.63$ & $4.24 \pm 0.56$ & $4.24 \pm 0.37$ & $0.21 \pm 0.07$ & $0.642 \pm 0.076$ & $0.722 \pm 0.042$ & 0.111 \\
DOM & 115 & $8.44 \pm 0.80$ & $4.12 \pm 0.56$ & $3.92 \pm 0.26$ & $1.61 \pm 0.19$ & $0.589 \pm 0.049$ & $0.719 \pm 0.037$ & 0.180 \\
N o t e. Na - the average number of alleles per locus, Ne - the average effective number of alleles per locus, \\
Ar - allele diversity, PrAr - the number of private alleles, $\mathrm{H}_{\mathrm{o}}-$ observed heterozygosity, $\mathrm{H}_{\mathrm{e}}-$ expected hetero- \\
zygosity, F F - inbreeding coefficient. See the description of the sub-populations in the Technique section. \\
\hline
\end{tabular}

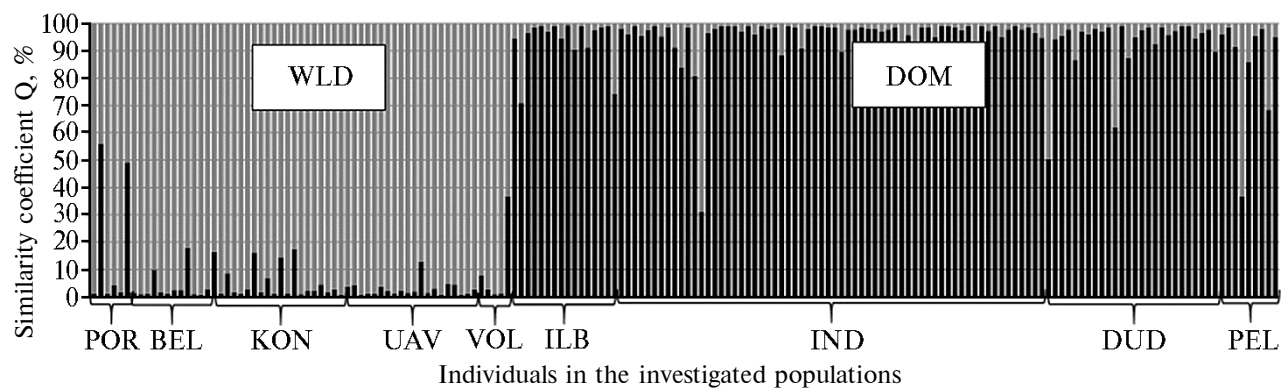

Fig. 2. Cluster analysis of wild (WLD) and domestic (DOM) reindeer (Rangifer tarandus L., 1758) populations by nine STR loci using STRUCTURE 2.3.4 [54] for the number of clusters $\mathrm{C}=2$. Q the contribution of each of the clusters to the species genotype (the probability that the species belongs to this or that cluster). For the domestic population is marked in black, for the wild one in grey. See the description of the sub-populations in the Technique section.

For cluster analysis, we determined the most probable number of clusters (C), or in other words, objectively isolated genetic groups in the sample in accordance to the algorithm based on the $\Delta \mathrm{C}$ values [56]. The optimum number of clusters for the sample was $\mathrm{C}=2(\Delta \mathrm{C}=87.23)$. The structure analysis with $\mathrm{C}=2$ (Fig. 2) showed a high genetic isolation both in wild and domestic reindeer populations, which is confirmed by the mean values of the similarity coefficient $\mathrm{Q}$ in each population $\left(\mathrm{Q}_{\mathrm{WLD}}=0.940 \pm 0.013\right.$ and $\left.\mathrm{Q}_{\mathrm{DOM}}=0.938 \pm 0.010\right)$. At the same time, we revealed three animals in the wild population $\left(\mathrm{Q}_{\mathrm{WLD}}=0.441\right.$, $\left.\mathrm{Q}_{\mathrm{WLD}}=0.508, \mathrm{Q}_{\mathrm{WLD}}=0.631\right)$, and five animals in the domestic population $\left(\mathrm{Q}_{\mathrm{DOM}}=0.310, \mathrm{Q}_{\mathrm{DOM}}=0.505, \mathrm{Q}_{\mathrm{DOM}}=0.621, \mathrm{Q}_{\mathrm{DOM}}=0.368, \mathrm{Q}_{\mathrm{DOM}}=0.684\right)$ (4.4 and $4.8 \%$ respectively) of a mixed genetic origin. Such mixed (crossbred) 
animals with a share of the other reindeer population's alleles in the genotype evidence a periodic gene exchange between these populations. The cluster analysis of the domestic population $(C=1-5)$ showed the homogeneous genetic structure of all the samples. Our results confirm the findings on the key morphobiological, growth and development parameters, and polymorphic protein blood systems that gave ground to consider the breed consolidated by its origin and genotype [58].

Despite the fact that the wild Taymyr reindeer population is represented by several isolated groups [10], according to N.V. Malygina [59] it should be regarded as a single whole ecological population. Probably that is why all samples of the Taymyr population that we studied were characterized by a common genetic structure without any clear clusterization between them (the analysis for the wild population at $\mathrm{C}=1-6)$.

AMOVA showed that $95.4 \%$ of genetic variability was the variability inside the samples of wild and domestic populations, and $4.6 \%$ was due to the variability between the populations $(\mathrm{p}<0.001)$.

The genetic variability in natural populations is generally indicative of the structure that emerges as a result of various processes (geographic isolation, progenitor effect, migration and admixture). One of the methods widely used to identify this structure of populations is the PCA analysis that determines two or three basic axes in the variability and plots tested objects in these coordinates [60]. This analysis based on the frequency of alleles in the studied populations makes it possible to simultaneously characterize the level of variability, to identify the key alleles contributing to the differentiation of animal groups, to track the key patterns of the population-genetic differentiation and to identify their relation to ecological and geographical factors [61]. The obtained results of the PCA are provided in Figure 3.

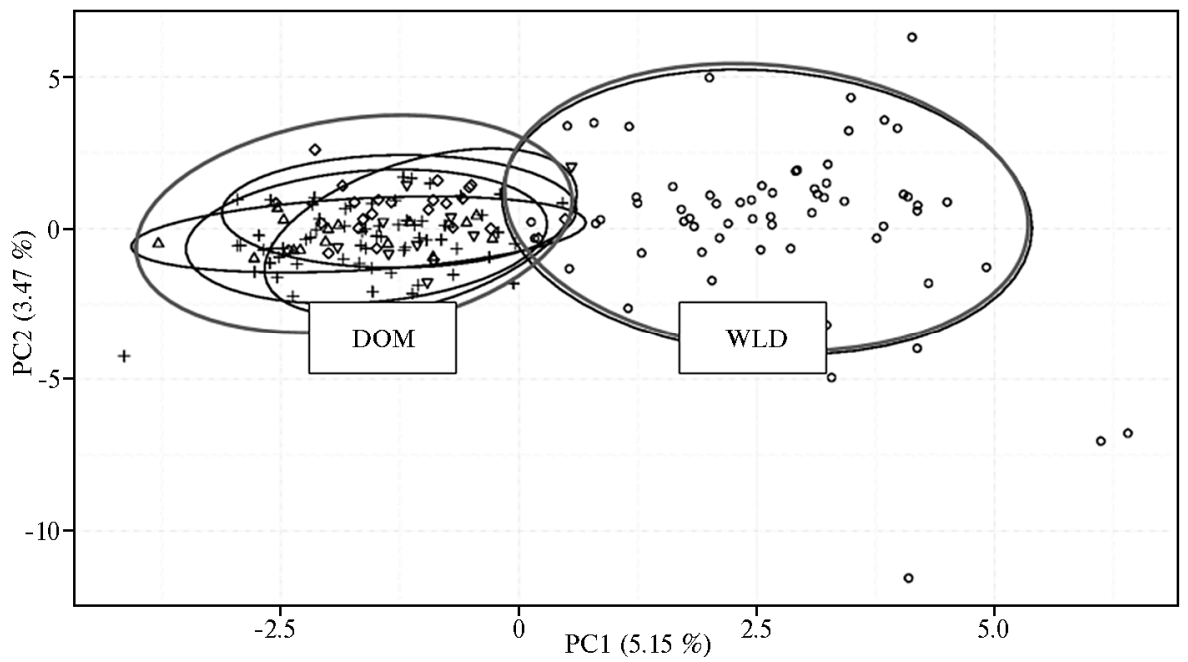

Fig. 3. Distribution of reindeer (Rangifer tarandus L., 1758) individuals from the wild (WLD) and domestic (DOM) populations within the space of two principal components: DOM - domestic population, $\triangle-$ ILB, +- IND, $\diamond-$ DUD, $\nabla-$ PEL. See the description of the sub-populations in the Technique section.

The first principal component reflected $5.15 \%$ of the observed variability of populations and clearly divided the domestic and wild reindeer populations. The insignificant overlay of the domestic and wild populations can be regarded as an indication of a non-controlled migration between them. According to A.V. Davydov [62], it is in the period of migrations that the herds of 
reindeer take away a part of domestic animals, and wild males that joined the domestic herds during the rutting period mate with females that resulted in up to $3 \%$ of the newborn reindeers. Within populations, reindeer from different subpopulations demonstrated similarity in the frequency of common alleles constituting a single genetic pool.

2. Genetic distances between the studied sub-populations of wild and domestic reindeer p (Rangifer tarandus L., 1758) opulations

\begin{tabular}{l|c|c|l|l|l|l|l|l|l}
\hline \multicolumn{1}{c}{ Sub-population } & POR & BEL & KON & UAV & VOL & ILB & IND & DUD & PEL \\
\hline POR & & 0.194 & 0.187 & 0.241 & 0.353 & 0.436 & 0.387 & 0.378 & 0.393 \\
BEL & 0.003 & & 0.122 & 0.191 & 0.324 & 0.402 & 0.369 & 0.339 & 0.368 \\
KON & 0.004 & 0.003 & & 0.119 & 0.230 & 0.397 & 0.349 & 0.328 & 0.320 \\
UAV & 0.024 & 0.021 & 0.009 & & 0.118 & 0.450 & 0.425 & 0.326 & 0.348 \\
VOL & 0.046 & 0.040 & 0.025 & 0.002 & & 0.562 & 0.521 & 0.400 & 0.387 \\
ILB & $0.097^{*}$ & $0.093^{*}$ & $0.096^{*}$ & $0.116^{*}$ & $0.150^{*}$ & & 0.072 & 0.094 & 0.151 \\
IND & $0.072^{*}$ & $0.074^{*}$ & $0.075^{*}$ & $0.099^{*}$ & $0.120^{*}$ & $0.008^{*}$ & & 0.077 & 0.101 \\
DUD & $0.076^{*}$ & $0.073^{*}$ & $0.075^{*}$ & $0.081^{*}$ & $0.097^{*}$ & $0.020^{*}$ & $0.015^{*}$ & & 0.113 \\
PEL & $0.047^{*}$ & $0.047^{*}$ & $0.045^{*}$ & $0.060^{*}$ & $0.066^{*}$ & 0.023 & 0.018 & 0.010 &
\end{tabular}

N ot e. The non-shifted distances according to $\mathrm{M}$. Nei $\left(\mathrm{D}_{\mathrm{N}}\right)$ are above the diagonal; the $\mathrm{F}_{\mathrm{ST}}$ values in the paired comparison are under the diagonal. See the description of the sub-populations in the Technique section.

* The differences for $\mathrm{F}_{\mathrm{ST}}$ are statistically significant at $\mathrm{p}<0.05$.

The calculations of $\mathrm{F}_{\mathrm{ST}}$ values in paired comparison and of the genetic distances according to $\mathrm{M}$. Nei $\left(\mathrm{D}_{\mathrm{N}}\right)$ [44] (Table 2) generally showed a relatively higher genetic differentiation of sub-populations within a wild population as compared to the domestic one: maximum $\mathrm{F}_{\mathrm{ST}}$ and $\mathrm{D}_{\mathrm{N}}$ values were 0.046 versus 0.023 and 0.353 versus 0.151 . Note, the genetically closer sub-populations were distinguished within the wild population than within the domestic population.

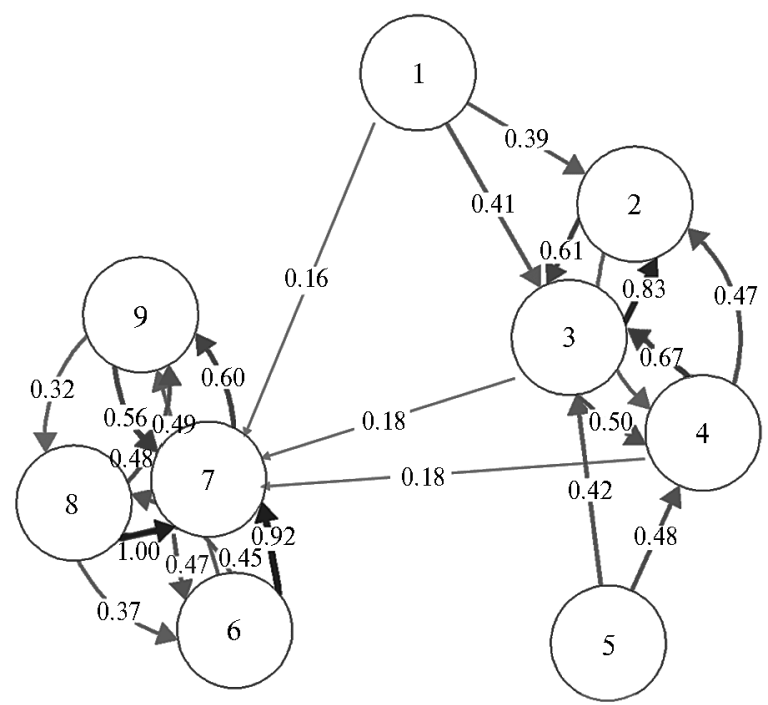

Fig. 4. Relative directed gene migration between reindeer (Rangifer tarandus L., 1758) populations visualized using the divMigrate model [48]: on the left - domestic population (DOM), on the right - wild population (WLD); 1 - POR, 2 - BEL, 3 - KON, 4 - UAV, 5 - VOL, 6 - ILB, 7 IND, 8 - DUD, 9 - PEL. See the description of the subpopulations in the Technique section.

network space [63].

The introgression of alleles between the domestic and wild populations was one way, i.e. from wild to domestic one (see Fig. 4). The maximum migration within the domestic population was identified between the sub-populations ILBIND and DUD-IND, where IND was a recipient of the gene flow from ILB and

Figure 4 provides an assessment of gene migration between reindeer populations. Studied samples of the individuals are shown as nods in networks. Each nod is hypothetically connected with every other nod by two lines representing two mutual components of gene flow between any of the population pairs. The length and thickness of each line changes depending on the intensity of the gene flow. Such characteristics are rather informative as they indicate the populations between which genes are exchanged with high intensity locally, but with low intensity outside the populations. The patterns of the population's genetic structure are presented as a single cluster in a 
DUD. For reindeer, the highest similarity was observed between the subpopulations BEL-KON-UAV, and the maximum migration occurred between UAV and BEL.

According to L. Sundqvis et al. [63], this approach shows graphically integrated network patterns of the gene flow between the populations and estimated the valid difference in the gene flow between the paired samples.

Scientists have always had increased interest in studying genetic diversity and introgressive hybridization in reindeer populations using genetic markers. The relationship between wild and domestic reindeer species was touched upon back in 1989 [64] and in early research works [65]. B. Jepsen et al. [66] found out the introgressive hybridization between wild caribou and domestic reindeer populations dwelling in the territory of Nuuk city (Greenland). M.A. Cronin et al. [67] identified common alleles for several genes present both in the wild and in domestic reindeer populations in Alaska suggesting insignificant genetic introgression in both directions. Hybrid animals are probably less adapted to wild life and captive crossbreeding is comparatively low [64, 68]. When studying the genetic diversity of migrating caribou populations in the Alaska North Slope and their potential hybridization with domestic reindeer, K.H. Mager et al. [69] discovered several individuals of mixed genetic origin $(8 \%$ in caribou populations and $14 \%$ among domestic reindeer).

It is expected that expanding the set of STR loci and increasing the sample size in both reindeer populations, including animals from other geographical points of the area, will make it possible to define more precisely the introgression in this species. The new-generation molecular markers based on the analysis of single nucleotide polymorphism (SNP) [70] may give more comprehensive insight into the interaction between wild and domestic reindeer populations on a genetic level. Understanding the genetic variability in reindeer populations within the whole area will help us see the evolution pattern of this species. Moreover, constant monitoring of genetic diversity and population size is required to preserve the wild reindeer.

Thus, based on microsatellite polymorphism we characterized the allele pool in the sample sets of two most numerous reindeer populations, the domestic Nenets reindeer and wild reindeer dwelling in the territory of Nenets Okrug and Taymyr Autonomous Okrug. Although the cluster analysis showed high genetic isolation of both forms, we identified several individuals of mixed genetic origin. The comparison of intrapopulation parameters revealed that wild reindeer have higher genetic diversity than domestic reindeer. Estimation of genetic diversity and the structure of Nenets breed population of reindeer is required for protestation and a sustainable use of its biological resources.

\section{REFEREN C ES}

1. $\mathrm{Mukhachev}$ A.D. Puteshestvie $v$ mir olenevodov [Journey to the reindeer herders' world]. Novosibirsk, 2001 (in Russ.).

2. Borozdin E.K., Zabrodin V.A., Vostryakov P.N. Severnoe olenevodstvo /Pod redaktsiei V.A. Zabrodina [Northern reindeer. V.A. Zabrodin (ed.)]. Moscow, 1979 (in Russ.).

3. I e rnslette n I.-L., K lo k o v K. Ilin, 2005, 1(42). Available: http://ilin-yakutsk.narod.ru/2005-1/18.htm. No date (in Russ.).

4. L o g i n o v V.G. Agrarnyi vestnik Urala, 2014, 11(129): 74-77 (in Russ.).

5. Y u z hak o v A.A. Nenetskaya aborigennaya poroda severnykh olenei. Avtoreferat doktorskoi dissertatsii [Indigenous Nenets reindeer. DSci Thesis]. Novosibirsk, 2004 (in Russ.).

6. Yu g a i V.K. Agrarnyi vestnik Urala, 2009, 10(64): 48-51 (in Russ.).

7. S t a m m le r F. Reindeer nomads meet the market: culture, property and globalisation at the end of the land. Lit-Verlag Muenster, 2005 (ISBN 3-8258-8046-x).

8. Ro m a n e n o T.M., Fili p p ov a G.I. Simvol nauki, 2015, 11: 44-52 (in Russ.).

9. Ernst L.K., D mitri e v N.G., P a ro n y a I.A. Geneticheskie resursy sel'skokhozyaistven- 
nykh zhivotnykh $v$ Rossii $i$ sopredel'nykh stranakh [Genetic diversity of farm animals in Russia and neighboring countries]. St. Petersburg, 1994 (in Russ.).

10. K o l p a h c h i k o L L.A. Taimyrskaya populyatsiya dikogo severnogo olenya (biologicheskie osnovy upravleniya $i$ ustoichivogo ispol'zovaniya resursov). Avtoreferat doktorskoi dissertatsii [Taimyr population of wild reindeer - biological aspects of control and sustainable use. DSci Thesis]. Noril'sk, 2000 (in Russ.).

11. Syroechkovski i E.E., Rogacheva E.V., S avchenko A.P., Sokolov G.A., B a ra nov A.A., Emel'y a nov V.I. Krasnaya kniga Krasnoyarskogo kraya. Redkie $i$ nakhodyashchiesya pod ugrozoi ischeznoveniya vidy zhivotnykh [Red Data Book of Krasnoyarsk region. Rare and endangered animal species]. Krasnoyarsk, 2000 (in Russ.).

12. Mukhachev A.D., Kolpash chikov L.A., La is hev K.A. Myasnaya produktivnost' severnykh olenei [Meat production in reindeer]. Novosibirsk, 2001 (in Russ.).

13. Ti k h o m i rov B.A. Vzaimosvyazi zhivotnogo mira i rastitel'nogo pokrova tundry [Relationships of wildlife and vegetation of the tundra]. Moscow-Leningrad, 1959 (in Russ.).

14. T is h k o v A.A. Zhurnal obshchei biologii, 1977, 38(1): 15-23 (in Russ.).

15. Kolpashchikov L.A., Mikhailov V.V. Sovremennye problemy prirodopol'zovaniya, okhotovedeniya i zverovodstva, 2012, 1: 108-109 (in Russ.).

16. S e m e n o v - Ty a n - S ha n s k i i O.I. Severnyi olen' [Reindeer]. Moscow, 1977 (in Russ.).

17. Klo k ov K.B. Materialy III Mezhdunarodnoi shkoly po yuridicheskoi antropologii "Olen' vsegda prav» [Proc. III Int. Workshop on anthropology of law «Reindeer is always right»]. St. Petersburg-Pushkin, 2003: 53-74 (in Russ.).

18. Sy ro e ch k ovski i E.E. Wild reindeer. Amerind Publishing, New Delhi, India, 1995.

19. B a s k i n L.M. Number of wild and domestic reindeer in Russia in the late 20th century. Rangifer, 2005, 25(1): 51-57 (doi: 10.7557/2.25.1.337).

20. P a p a R. Gene flow and introgression between domesticated crops and their wild relatives. Proc. Int. Workshop "The role of biotechnology for the characterization and conservation of crop, forestry, animal and fishery genetic resources». Turin, Italy, 2005: 71-76.

21. M a c H u g h D.E., B rad le y D.G. Livestock genetic origins: goats buck the trend. PNAS USA, 2001, 98: 5382-5384 (doi: 10.1073/pnas.111163198).

22. Bruford M.W., Bradley D.G., Luikart G. DNA markers reveal the complexity of livestock domestication. Nat. Rev. Genet., 2003, 4: 900-910 (doi: 10.1038/nrg1203).

23. M a c Hugh D.E., Shriver M.D., Loftus R.T., Cunningham P., Bradley D.G. Microsatellite DNA variation and the evolution, domestication and phylogeography of taurine and zebu cattle (Bos taurus and Bos indicus). Genetics, 1997, 146: 1071-1086.

24. Luikart G., Gielly L., Excoffier L., Vigne J.-D., Bouvet J., Taberlet P. Multiple maternal origins and weak phylogeographic structure in domestic goats. PNAS USA, 2001, 98: 5927-5932 (doi: 10.1073/pnas.091591198).

25. B a sk i n L.M. Reindeer husbandry in the Soviet Union. Wildlife production systems: economic utilization of wild ungulates. R.J. Hudson, K.R. Drew, L.M. Baskin (eds.). Cambridge University Press, Cambridge, UK, 1989: 197-206.

26. S $\mathrm{t}$ a a $\mathrm{l}$ a $\mathrm{nd}$ H., E i k e $1 \mathrm{~m}$ a $\mathrm{n}$ I.M.H. Status of the reindeer industry in Fennoscandia. Wildlife production: conservation and sustainable development. L.A. Renecker, R.J. Hudson (eds.). AFES Misc. University of Alaska, Fairbanks, 1991, 91(6): 77-88.

27. Davydov A.V., Kholodova M.V., Meshcherskii I.G., Gruzdev A.R., Sipko T.P., Kol N.V., Tsarev S.A., Zheleznov-Chukotskii N.K., Mirutenko V.S., Gubar' Yu.P., Li n'kov A.B., Rozhkov Yu.I. Differentiation of wild and domestic forms of caribou (Rangifer tarandus L.) on the results of mtDNA analysis. Sel'skokhozyaistvennaya biologiya [Agricultural Biology], 2007, 6: 48-53. Available http://agrobiology.ru/articles/6-2007davydov.pdf. No date (in Russ.).

28. Khokhlov A.M. Teoreticheskoe obosnovanie protsessa domestikatsii, selektsionnogeneticheskii $i$ tekhnologicheskii monitoring $v$ svinovodstve. Avtoreferat doktorskoi dissertatsii [Theoretical aspects of domestication, genetic and technological monitoring in pigbreeding. DSci Thesis]. Khar'kov, 2006 (in Russ.).

29. B a 11 M.C., Finnegan L., M a n s e a u M., Wils o n P. Integrating multiple analytical approaches to spatially delineate and characterize genetic population structure: an application to boreal caribou (Rangifer tarandus caribou) in central Canada. Conserv. Genet., 2010, 11: 21312143 (doi: 10.1007/s10592-010-0099-3).

30. Z Z t t l a u K.A. Population genetic analyses of North American caribou (Rangifer tarandus). PhD Thesis. University of Alberta, Canada, 2004.

31. Cronin M.A., Mac N e il M.D., Pat to n J.C. Variation in mitochondrial DNA and microsatellite DNA in caribou (Rangifer tarandus) in North America. J. Mammal., 2005, 86: 495505 (doi: 10.1644/1545-1542(2005)86[495:VIMDAM]2.0.CO;2).

32. Tyler S.K., M c farlane K.A., Pamela Groves P., Mooers A.Ø., Shapiro B. Modern and ancient DNA reveal recent partial replacement of caribou in the southwest Yukon. Mol. Ecol., 2010, 19: 1312-1323 (doi: 10.1111/j.1365-294X.2010.04565.x).

33. Kharzinova V.R., Gladyr' E.A., Fedorov V.I., Ro manenko T.M., Shi m - 
it L.D., Layshev K.A., Ka lashnikova L.A., Z inovieva N.A. Development of multiplex microsatellite panel to assess the parentage verification in and differentiation degree of reindeer populations (Rangifer tarandus). Agricultural Biology, 2015, 50(6): 756-765 (doi: 10.15389/agrobiology.2015.6.756eng) (in Engl.).

34. Pfeiffer A., Olivieri A.M., Morgante M. Identification and characterization of microsatellites in Norway spruce (Picea abies K.). Genome, 1997, 40: 411-419.

35. Scotti I., Magni F., Paglia G.P., Morgante M. Trinucleotide microsatellite in Norway spruce (Picea abies): their features and the development of molecular markers. Theor. Appl. Genet., 2002, 106: 40-50 (doi: 10.1007/s00122-002-0986-1).

36. Fluch S., Burg A., Kopecky D., Homolka A., Spiess N., Vendramin G.G. Characterization of variable EST SSR markers for Norway spruce (Picea abies L.). BMC Res. Not., 2011, 4: 401-412 (doi: 10.1186/1756-0500-4-401).

37. Cremer E., Liepelt S., Sebastiani F., Buonamici A., Michalczyk I.M., $\mathrm{Z}$ i e g e $\mathrm{nh}$ a ge $\mathrm{n}$ B., Ve nd ramin G.G. Identification and characterization of nuclear microsatellite loci in Abies alba Mill. Mol. Ecol. Notes, 2006, 6: 374-376 (doi: 10.1111/j.14718286.2005.01238.x).

38. Kahle D., Wi ck h m H. ggmap: Spatial visualization with ggplot2. The $R$ Journal, 2013, 5(1): 144-161.

39. W i c k h a m H. ggplot2: Elegant graphics for data analysis. Springer-Verlag, NY, 2009.

40. B row n A.H.D., W e i r B.S. Measuring genetic variability in plant populations. In: Isozymes in plant genetics and breeding, Part A. S.D. Tanksley, T.J. Orton (eds.). Elsevier Science Publ., Amsterdam, 1983.

41. Ka li nowski S.T. Counting alleles with rarefaction: Private alleles and hierarchical sampling designs. Conserv. Genet., 2004, 5: 539-543 (doi: 10.1023/B:COGE.0000041021.91777.1a).

42. H a r 1 D.L., C 1 a r k A.G. Principles of population genetics. Sunderland, Massachusetts, 1997.

43. We i r B.S., C o cke rha m C.C. Estimating F-statistics for the analysis of population structure. Evolution, 1984, 38: 1358-1370.

44. N e i M. Genetic distance between populations. Am. Nat., 1972, 106(949): 283-292 (doi: 10.1086/282771).

45. Peakall R., S mouse P.E. GenAlEx 6.5: genetic analysis in Excel. Population genetic software for teaching and research - an update. Bioinformatics, 2012, 28: 2537-2539 (doi: 10.1093/bioinformatics/bts460).

46. Kalinowski S.T. HP RARE 1.0: a computer program for performing rarefaction on measures of allelic richness. Mol. Ecol. Notes, 2005, 5: 187-189 (doi: 10.1111/j.14718286.2004.00845.x).

47. B e lkhir K., B orsa P., Chikhi L., Raufaste N., B o n hom me F. GENETIX 4.05, logiciel sous Windows TM pour la génétique des populations. Laboratoire Génome, Populations, Interactions, CNRS UMR 5171, Université de Montpellier II, Montpellier (France), 1996-2004.

48. S u nd q vis t L., Z a c k r is s o $\mathrm{n}$ M.Z., K l e i $\mathrm{n} \mathrm{han} \mathrm{s} \mathrm{D.} \mathrm{Directional} \mathrm{genetic} \mathrm{differentiation} \mathrm{and}$ asymmetric migration. Available https://arxiv.org/abs/1304.0118 [q-bio.PE]. No date.

49. Ke e nan K., Mc Ginnity P., C ross T.F., Crozier W.W., Prodohl P.A. diveRsity: An R package for the estimation of population genetics parameters and their associated errors. Methods in Ecology and Evolution, 2013, 4: 782-788 (doi: 10.1111/2041-210X.12067).

50. Meirmans P.G., Hedrick P.W. Assessing population structure: FST and related measures. Mol. Ecol. Resour., 2011, 11: 5-18 (doi: 10.1111/j.1755-0998.2010.02927.x).

51. J o st L. GST and its relatives do not measure differentiation. Mol. Ecol., 2008, 17: 4015-4026 (doi: 10.1111/j.1365-294X.2008.03887.x).

52. J o m b a r t T. adegenet: a R package for the multivariate analysis of genetic markers. Bioinformatics, 2008, 24: 1403-1405 (doi: 10.1093/bioinformatics/btn129).

53. Ex c offie r L., Lis c he r H.E.L. Arlequin suite ver 3.5: A new series of programs to perform population genetics analyses under Linux and Windows. Mol. Ecol. Resour., 2010, 10: 564567 (doi: 10.1111/j.1755-0998.2010.02847.x).

54. Pritchard J.K., Stephens M., D o n ne 11 y P. Inference of population structure using multilocus genotype data. Genetics, 2000, 155: 945-959.

55. E a r l D.A., vo n Holdt B.M. Structure Harvester: A website and program for visualizing Structure output and implementing the Evanno method. Conserv. Genet. Resour., 2012, 4: 359361 (doi: 10.1007/s12686-011-9548-7).

56. Evanno G., Regnaut S., Goudet J. Detecting the number of clusters of individuals using the software STRUCTURE: A simulation study. Mol. Ecol., 2005, 14: 2611-2620 (doi: 10.1111/j.1365-294X.2005.02553.x).

57. $\mathrm{M}$ a g e $\mathrm{r}$ K.H. Population structure and hybridization of Alaskan caribou and reindeer: integrating genetics and local knowledge. Dissertation of the degree doctor of philosophy. Fairbanks, Alaska, 2012.

58. Y u z hak o v A.A. Nenetskaya aborigennaya poroda severnykh olenei. Avtoreferat doktorskoi dissertatsii [Indigenous Nenets reindeer. DSci Thesis]. Novosibirsk, 2004 (in Russ.).

59. M a ly gi n a N.V. Dikii severnyi olen' (Rangifer tarandus L.) Vostochnogo Taimyra. Avtoreferat 
kandidatskoi dissertatsii [Reindeer (Rangifer tarandus L.) of eastern Taimyr. PhD Thesis]. Moscow, 2000 (in Russ.).

60. M c Ve a n G. A genealogical interpretation of principal components analysis. PLoS Genet., 2009, 5(10): e1000686 (doi: 10.1371/journal.pgen.1000686).

61. Y u r c h e n k o A.A. Geneticheskaya struktura populyatsii sakhalinskogo taimenya Parahucho perryi brevoort $i$ voprosy prirodookhrannoi genetiki vida. Avtoreferat kandidatskoi dissertatsii [Genetic structure of Parahucho perryi brevoort population and conservation genetics of the species. $\mathrm{PhD}$ Thesis]. Moscow, 2015 (in Russ.).

62. D a v y d o v A.V. Morfologicheskaya i geneticheskaya differentsiatsiya populyatsii severnogo olenya Evrazii. Avtoreferat kandidatskoi dissertatsii [Morphological and genetic differentiation of the Eurasian reindeer populations. PhD Thesis]. Moscow, 1997.

63. Sundquist L., Keenan K., Zackrisson M., Prodöhl P., Kleinhans D. Directional genetic differentiation and asymmetric migration. Ecol. Evol., 2016, 6(11): 3461-3475 (doi: 10.1002/ece3.2096).

64. B u rn s J.J. Report of the scientific workshop on caribou in the NPRA. Barrow, Alaska, 1989.

65. Kle i n D.R. Conflicts between domestic reindeer and their wild counterparts: A review of Eurasian and North American experience. Arctic, 1980, 33: 739-756.

66. J e p s e n B., S i e g i s mu nd H., Fre d hol m M. Population genetics of the native caribou (Rangifer tarandus groenlandicus) and the semi-domestic reindeer (Rangifer tarandus tarandus) in Southwestern Greenland: Evidence of introgression. Conserv. Genet., 2002, 3: 401-409 (doi: 10.1023/A:1020523303815).

67. Croni n M.A., Re ne cke r L.A., P i e rson B.J., Pat to n J.C. Genetic variation in domestic reindeer and wild caribou in Alaska. Anim. Genet., 1995, 26: 427-434 (doi: 10.1111/j.1365-2052.1995.tb02695.x).

68. Cronin M.A., Pat t o n J.C., B a $1 \mathrm{mys}$ heva N., M a c N e il M.D. Genetic variation in caribou and reindeer (Rangifer tarandus). Anim. Genet., 2003, 34: 33-41 (doi: 10.1046/j.13652052.2003.00927.x).

69. M a g e r K.H., C ols o n K.E., Hu nd e rt ma rk K.J. High genetic connectivity and introgression from domestic reindeer characterize northern Alaska caribou herds. Conserv. Genet., 2013, 14: 1111-1123 (doi: 10.1007/s10592-013-0499-2).

70. K h a rzinova V.R., S e rmyag in A.A., G lad y r E.A., O khlopkov I.M., B rem G., Zinovieva N.A. A study of applicability of SNP chips developed for Bovine and Ovine species to whole-genome analysis of reindeer Rangifer tarandus. J. Heredity, 2015, 106(6): 758-761 (doi: 10.1093/jhered/esv081).

\section{Events \\ RNA THERAPEUTICS}

(22-23 February, 2017, London, United Kingdom)

SMi Group announces the return of its $8^{\text {th }}$ annual RNA Therapeutics conference to London on the 22nd-23rd of February 2017. Technology in RNA interference, oligonucleotides and mRNA has revolutionised the way infectious disease, cancer and neurological disorders are treated. It is now possible to target previously 'un-druggable' sites, therefore expanding the range of therapeutics that selectively silence genes before the disease develops.

This exciting program for 2017 will showcase new developments through clinical and pre-clinical results in topics such as: messenger RNA-based therapeutics, anti-sense oligonucleotides and new sites for RNA silencing.

The main challenge in RNA therapeutics continues to be the delivery of RNA based drugs to target sites outside the liver. Join us in exploring the different delivery systems in use and in development such as transportation with nanoparticles and the ability to enhance drug stability.

We will be reviewing clinical trial updates in RNA-based therapeutics and discussing the current regulations involved in getting drug approval.

Contacts: https://www.cambridgenetwork.co.uk/news/astrazeneca-and-moderna-therapeutics-announcenew-collaboration

Information: http://www.globaleventslist.elsevier.com/events/2016/04/the-application-of-molecular-andfunctional-imaging-in-neurodegenerative-disease/ 